\title{
Analysis of monosaccharide composition of fucoidan from Sargassum horneri using UPLC-DAD-TOF/MS combined with precolumn derivatization by 3-methyl-1-phenyl-5-pyrazolone
}

\author{
Joon Ho Hong ${ }^{1}$, Mi Jin Lee ${ }^{1}$, Sang Ji Moon ${ }^{1}$, Dong Sub Kim ${ }^{2}$, Eun Yeong Nho ${ }^{3}$, \\ Ji Yeon $\mathrm{Choi}^{3}$, Kyong $\mathrm{Su} \mathrm{Kim}{ }^{3 *}$ \\ ${ }^{1}$ Nano Bio Research Center, Jeonnam Bioindustry Foundation, Jangsung 57248, Korea \\ ${ }^{2}$ Korea Prime Pharm Co., Ltd., Gwangju 61473, Korea \\ ${ }^{3}$ Department of Food and Nutrition, Chosun University, Gwangju 61452, Korea
}

\section{3-Methyl-1-phenyl-5-pyrazolone 유도체화와 UPLC-TOF/MS를 이용한 괭생이모자반 유래 푸코이단의 단당류의 조성 분석}

\author{
홍준호 $^{1} \cdot$ 이미진 ${ }^{1} \cdot$ 문상지 $^{1} \cdot$ 김동섭 $^{2} \cdot$ 노은영 $^{3} \cdot$ 최지연 $^{3} \cdot$ 김경수 $^{3 *}$ \\ ${ }^{1}$ (재)전남생물산업진흥원 나노바이오연구센터, ${ }^{2}$ 한국프라임제약(주), ${ }^{3}$ 조선대학교 식품영양학과
}

\begin{abstract}
The simple, effective, and sensitive method for analyzing monosaccharide composition of fucoidan using UPLC-DAD-TOF/MS combined with precolumn derivatization by 3-methyl-1-phenyl-5-pyrazolone (PMP) reagent. This method is used to identify and quantify the monosaccharide composition in fucoidan from Sargassum horneri. The UPLC method with PMP precolumn derivatization is reported (simple, rapid, convenient and reproducible) and it also proved to be suitable for the UPLC analysis of fucoidan. Also, this method can be used for determination of monosaccharide contents in other seaweed polysaccharides by changing the $\mathrm{pH}$ value of the mobile phase. In order to ensure reliability, this analytical method was validated by analyzing the linearities, precisions, and recovery rates of mixed standard solutions of mannose and other monosaccharides. Fucoidan derived from $S$. horneri is composed of mannose, glucose, galactose, xylose, glucuronic acid, rhamnose and fucose, with the fucose content found to exceed $50 \%$ of the fucoidan composition. The results of this study help to structurally analyze the fucoidan from $S$. horneri. It is expected that the analytical method established in this study will be useful for the standardization and development of functional raw materials from $S$. horneri.
\end{abstract}

Key words : Sagarssum horneri, fucoidan, monosaccharide, PMP derivatization, UPLC-DAD-TOF/MS

\section{서 론}

해조류는 약 36,000 여 종이 전 세계각지에 분포하고 있고 우리나라에는 약 1,000 여 종의 해조류가 서식하고 있는 것 으로 추정하고 있으며 동아시아 국가를 중심으로 생태학적

*Corresponding author. E-mail : kskim@chosun.ac.kr Phone : 82-62-230-7724, Fax : 82-62-224-8881

Received 02 January 2019; Revised 20 February 2019; Accepted 04 March 2019.

Copyright (c) The Korean Society of Food Preservation. All rights reserved.
측면과 경제적 측면에서 중요한 해양생물 자원으로 인식되 어 해조류에 대한 증식과 활용 방안에 관한 연구가 활발히 진행되고 있다. 해조류는 열량이 매우 낮으면서 다양한 무 기질과 식이섬유 및 아미노산 등이 풍부하고 육상식물에는 없는 점질성 다당류를 다량 함유하고 있어(1) 한국과 일본 에서는 식용으로 사용하고 있지만 미국과 유럽 등지에서는 주로 동물 사료로 사용되고 있다. 최근에는 해조류의 다양 한 생리활성이 밝혀지면서 인체에 유용한 기능성 식품으로 개발하고자 하는 노력이 기울어지고 있다(2)

기능성 다당류의 일종인 푸코이단은 갈조류에서 1913년 Kylin에 의해 처음 분리된 후(3) 성게, 해삼과 같은 해양 
유래 무척추동물에도 푸코이단이 함유되어 있는 것으로 밝혀졌다(4). 주로 갈조류에 함유되어 있는 푸코이단은 세 포벽의 구성성분으로 열수나 산 용액에 용해되는 것으로 보고되었다(5). 푸코이단은 함황 다당류로서 L-fucose을 기본 구성당으로 $\mathrm{a}(1 \rightarrow 2)$ 결합된 $\mathrm{a}-\mathrm{L}-\mathrm{fucose}-4$-sulfate의 기본 골 격과(6), mannose, glucose, galactose, xylose, glucuronic acid, rhamnose 등이 결합된 구조이다. 일반적으로 푸코이단은 L-fucose의 에스테르화 황산을 주성분으로 glucuronic acid 를 함유한 U-푸코이단, 황산 fucose로 구성된 F-푸코이단, 그리고 galactose를 함유한 $\mathrm{G}$-푸코이단으로 구분되며(7) 종 에 따라서 $a(1 \rightarrow 2)$ 대신 $a(1 \rightarrow 3)$ 결합 또는 $a(1 \rightarrow 3)$ 및 $a(1 \rightarrow 4)$ 결합이 복합적으로 존재하는 경우도 있다(8). 해조류 유래 푸코이단은 항염증, 항산화, 항균, 항응고, 항당뇨, 세포사 멸 활성 등과 같은 다양한 생리활성이 있는 것으로 보고되 고(9-12) 있는 반면, 푸코이단의 추출 조건 확립과 구조 및 이를 구성하는 단당류 조성에 관한 국내 연구는 미비한 실정이다. 푸코이단의 다양한 기능성에도 불구하고 해조류 유래 푸코이단의 구조 및 조성은 명확하게 규명되어 있지 않다. 푸코이단의 생리활성에 영향을 미치는 요인으로는 푸코이단의 단당류의 조성 구조, 구성성분 등이 있으며 최 근 몇몇 연구들에 따르면, 푸코이단의 구성성분 중 황산기 의 함량이 생리활성과 관련이 있는 것으로 제기되고 있는 수준에 불과하다. 이에 따라 해조류로부터 생산된 푸코이 단에 대한 단당류 조성 등의 기본 정보를 제공할 수 있는 분석법과 이를 활용한 품질관리 기준 마련이 시급하다.

단당류는 매우 유사한 구조의 다수 동족체로 존재하고 다양한 형태의 올리고당과 다당류 및 당단백질 형태로 존재 하기 때문에 단당류 분석은 필연적으로 고분해능의 분리 분석이 요구된다. 단당류는 화학구조적 특징으로 수십 $\mathrm{ppm}$ 이하의 농도 검출이 불가능하나 특정 시약과 단당류와 적정 조건에서 반응시켜 유도체화함으로서 검출감도 등의 분리 분석 효율을 향상시킬 수 있다. Honda 등(13)은 비교적 낮은 온도 조건에서 3-methyl-1-phenyl-5-pyrazolone(PMP)이 단 당류과 반응하여 $250 \mathrm{~nm}$ 에서 강한 자외선 흡수를 갖는 고감도의 유도체를 생성한다고 보고하였고 PMP를 이용한 유도체화 방법은 초기에 HPLC를 이용한 단당류 분석으로 적용되었으며 이후 모세관 전기영동에 성공적으로 적용 확대되기도 하였다 $(14,15)$.

한편, 갈조식물문(phaeophyta)의 모자반과(Sargassaceae) 모자반속(Sargassum)에 속하는 괭생이모자반(Sargassum horneri (Turner) C. Agardh)은 동아시아 지역에 폭넓게 분포 되어 있는 식용 해조류이다. 괭생이모자반(S. horneri)은 한 국, 일본 및 중국 연안에 폭넓게 분포하는 종으로 해류를 타고 이동하는 부유성 해조류로 알려져 있다 $(16,17)$. 최근 중국 저장성의 해양경제혁신발전구역 조성으로 괭생이모 자반 양식증대사업이 추진되는 가운데 자연 조락 및 풍랑으 로 인해 암반에서 탈락된 괭생이모자반이 해류와 북서계절
풍의 기류를 따라 우리나라 남해안과 제주지역으로 대량 유입되고 있는 실정이다(18). 이에 괭생이모자반 유래 푸코 이단에 대한 기능성 규명 등 식품 산업적 활용가치를 극대 화하기 위한 노력이 추진되고 있다.

본 연구에서는 해조류 유래 푸코이단의 단당류 조성 분 석을 위한 PMP 유도체화와 UPLC-DAD-TOF/MS 분석법 적용을 검토하였고 이를 바탕으로 괭생이모자반 유래 푸코 이단의 구성 단당류 조성과 함량을 확인하였으며 향후 기능 성 식품 소재 개발 등에 필요한 기초자료를 제공하고자 하였다.

\section{재료 및 방법}

\section{실험재료 및 시약}

시료는 2017년 5월 완도에서 수거한 괭생이모자반( $S$. horneri) 건조물을 구입하여 사용하였으며 $5-10 \mathrm{~cm}$ 로 절단 한 후 건물 기준으로 40 배수의 정제수를 이용하여 불린 후 $30 \mathrm{~min}$ 동안 삶아 이물질 등을 제거한 다음 $50^{\circ} \mathrm{C}$ 에서 열풍건조하였다. 이때 수분 함량은 $5 \%$ 이하로 확인하였고 건조된 시료는 분쇄기(Blender 8010S, Waring Conair Co., Ltd., Stamford, CT, USA)를 이용하여 분쇄 및 균질화 후 밀봉하여 상온의 진공 제습기에 보관하면서 사용하였다. 괭생이모자반 추출물은 Kim 등(19)과 Yoon 등(20)의 추출 용매 및 온도조건을 참고하여 $90^{\circ} \mathrm{C}$ 에서 4 시간 동안 열수추 출하고, 고형분 함량이 $20 \% \mathrm{Brix}$ 가 되도록 감압농축 (Evaporator, CEP-LABO, Okawahara, Japan) 한 다음 분무건 조(Spray dryer, HKC-100-DJ, Niro, Denmark)한 것을 열수 추출물로 사용하였다.

본 연구에 사용한 PMP 등의 시약과 용매는 특급시약 (extra pure grade)과 HPLC급으로 Sigma-Aldrich Co., Ltd.(St. Louis, MO, USA), Burdick and Jackson Laboratories (Muskegon, MI, USA)에서 구입하였으며, 정제수는 초순수 $\mathrm{k}$ 제조장치(Arium comport I, Sartorius, Germany)에서 얻은 resistivity $18.2 \mathrm{M} \Omega \cdot \mathrm{cm}$, TOC $2 \mathrm{ppb}$ 이하의 ultrapure water grade를 사용하였다. 단당류의 확인 및 정량 분석은 mannose, rhamnose, glucuronic acid, glucose, galactose, xylose 및 fucose 표준물질을 혼합한 후 정제수로 용해하여 $10,000 \mu \mathrm{g} / \mathrm{mL}$ 의 표준원액을 조제하고 이를 $10-500 \mu \mathrm{g} / \mathrm{mL}$ 의 농도범위로 희석한 것을 혼합표준용액으로 사용하였다. PMP 유도체 시액은 유도체화 반응 전에 methanol로 용해하 여 0.5 M PMP-MeOH로 조제하였다.

\section{푸코이단의 가수분해}

푸코이단의 가수분해는 Fu와 Oneill(14)의 방법에 따라 건조 괭생이모자반 $0.1 \mathrm{~g}$ 에 $2 \mathrm{M}$ trifluoroacetic acid(TFA) $10 \mathrm{~mL}$ 를 가하여 밀봉하여 $100^{\circ} \mathrm{C}$ 에서 $120 \mathrm{~min}$ 동안 가열한 
후 실온에서 방냉하였다. 분해를 마친 시료는 $0.45 \mu \mathrm{m} \mathrm{PTFE}$ membrane syringe filter(Whatman International, Maidstone, $\mathrm{UK})$ 으로 여과한 후 $2 \mathrm{M}$ sodium hydroxide $(\mathrm{NaOH})$ 를 이용하 여 $\mathrm{pH} 7$ 로 조정한 다음 시료 총량이 $30 \mathrm{~mL}$ 이 되도록 정용하 였다.

\section{3-Methyl-1-phenyl-5-pyrazolone(PMP) 유도체화}

가수분해된 단당류와 PMP 유도체 반응은 Honda 등(15) 의 방법에 따라 가수분해 시료 $2 \mathrm{~mL}$ 를 취하여 $0.5 \mathrm{M}$ $\mathrm{PMP}-\mathrm{MeOH}$ 용액과 $0.3 \mathrm{M} \mathrm{NaOH}$ 용액 각 $2 \mathrm{~mL}$ 씩 첨가하여 교반한 다음 $70^{\circ} \mathrm{C}$ 로 미리 가열된 수옥조에서 $30 \mathrm{~min}$ 동안 반응시킨 후 실온에서 방냉하였다. 이후 $0.3 \mathrm{M} \mathrm{HCl} 2 \mathrm{~mL}$ 를 첨가하여 고형물이 형성될 때까지 약 $1 \mathrm{~min}$ 동안 교반하고 chloroform $4 \mathrm{~mL}$ 를 가하여 진탕한 다음 $20^{\circ} \mathrm{C}, 1,500 \mathrm{rpm}$ 으로 $15 \mathrm{~min}$ 동안 원심분리하여 $\mathrm{PMP}$-유도체화물 이외 성분을 제거하였으며 수상의 상등액을 $0.45 \mu \mathrm{m}$ PTFE membrane syringe filter로 여과 후 UPLC-DAD로 분석하였다. Fucose 등의 혼합표준용액도 동일 방법으로 처리하여 괭생이모자 반 유래 푸코이단의 단당류의 조성 및 함량을 확인하였다.

\section{UPLC-DAD-TOF/MS 분석조건}

해조류 유래 다당류의 단당류 조성 및 함량 확인을 위해 가수분해 후 유도체화물(derivatives)인 PMP-sugars을 다중 파장 검출기(photodiode array detector, PDA)가 장착된 UPLC(Nexera XR, Shimadzu, Kyoto, Japan)와 UPLC-ESITOF/MS(LCMS-IT-TOF ${ }^{\circledR}$, Shimadzu)를 이용하였다. 분석 컬럼은 Capcell Core $\mathrm{C}_{18}(2.1 \mathrm{~mm}$ I.d. $\times 150 \mathrm{~mm} \mathrm{~L}, 2,7 \mathrm{um}$, Shiseido, Tokyo, Japan)을 사용하였고 이동상은 $100 \mathrm{mM}$ ammonium acetate(A)와 acetonitrile(B)을 80:20\% (v/v)의 등 용리 조건으로 설정하고 유량은 $0.2 \mathrm{~mL} / \mathrm{min}$ 로 하였다. 이때 이동상의 $\mathrm{pH}$ 는 4-7 범위의 조건에서 각 PMP-sugars의 분리 특성을 확인하여 최적의 조건을 검토하였다. 컬럼 온도는 $35^{\circ} \mathrm{C}$ 를 유지하고 시료는 $5 \mu \mathrm{L}$ 를 주입하였다. 검출파장은 다중 파장으로 200-600 nm 범위로 설정하였고 분리분석된 PMP-sugars의 UV 스펙트럼를 확인하여 최대 흡수파장 (wavelength of maximum absorption, $\lambda_{\max }$ )으로 크로마토그 램을 나타내었다. 질량 분석은 전기분무화 이온화 (electrospray ionization, ESI)를 이용하였으며 positive ion mode로 분석하였다. ESI capillary의 전압은 $4.5 \mathrm{kV}$, nebulizing $\operatorname{gas}\left(\mathrm{N}_{2}\right)$ 와 drying gas는 각각 $1.5 \mathrm{~L} / \mathrm{min}$ 과 150 $\mathrm{kPa}$ 로 설정하였다. $\mathrm{CDL}$ 과 block heater는 $200^{\circ} \mathrm{C}$ 로 설정하였 고, 데이터 수집 시간은 $0.3 \mathrm{~min}$ (event time $300 \mathrm{msec}$, repeat 3 , ion accumulation $10 \mathrm{msec}$ )으로 하였다. 질량분석 범위는 $\mathrm{m} / \mathrm{z}$ 100-1,000으로 설정하였다. 질량 분석 결과는 shimadzu 사의 LCMS solution(ver. 3.60)과 accurate mass calculator 전용 소프트웨어인 formula predictor(ver. 1.2)를 활용하여 해석하였으며, TOF(time of flight) 질량 분석기는 주기적인 tune 실행으로 $\pm 0.005 \mathrm{Da}$ 이하의 질량 정확도(mass accuracy)를 유지하면서 본 실험을 수행하였다.

\section{분석방법 검증}

본 연구에서는 유효성 검증을 위해 직선성(linearity), 정 밀성(precision), 정확성(accuracy), 검출한계(limit of detection, LOD) 및 정량한계(limit of quantitation, LOQ)를 확인하였 다. 특이성은 가수분해 및 유도체화의 과정을 거친 혼합표 준용액과 괭생이모자반 추출물 시료를 대상으로 UPLC로 분석하여 각 성분이 선택적으로 분리되었는지 확인하였으 며 크로마토그램상의 $t_{R}$ 과 UV 및 mass spectrum의 일치 여부를 비교, 확인하였다. 직선성은 혼합표준용액을 단계 적으로 일정농도로 희석하여 3 회 반복 측정한 후 검량선을 작성하여 검량식과 상관계수(correlation coefficient, $\mathrm{r}^{2}$ )를 산출하여 확인하였다. 정밀성은 일내(intra-day) 반복 분석 을 통해 상대표준편차(relative standard deviation, \% RSD) 를 산출하여 확인하였고, 정확성은 공시료에 일정 농도로 조제된 혼합표준용액을 가하고 동일 전처리 과정를 거친 시료를 대상으로 회수율(recovery)을 확인하였다. 검출한계 와 정량한계는 검량선의 기울기와 표준편차를 이용하여 다음 식과 같이 산출하였다.

$$
\begin{aligned}
& \mathrm{LOD}=3.3 \delta / \mathrm{S} \\
& \mathrm{LOQ}=10 \delta / \mathrm{S}
\end{aligned}
$$

$\delta:$ The standard deviation of the response

S : The slope of the calibration curve

\section{통계처리}

모든 실험은 5 회 이상 반복 측정하였고, 실험결과의 유의 성을 검정하기 위하여 $\mathrm{SPSS}^{\circledR}$ statistics ver $23\left(\mathrm{IBM}^{\circledR}\right.$, Armonk, NY, USA)를 이용하여 독립표본 t-test와 일원배치 분산분석(one-way ANOVA) 실시하여 Tukey b range test로 시료간의 유의차를 검정하고 그 결과는 평균과 표준편차 $(m e a n \pm \mathrm{SD})$ 로 표시하였다.

\section{결과 및 고찰}

단당류 유도체화물(PMP-sugars)의 분리 특성 및 동정 푸코이단은 전통적으로 Dische법으로도 알려져 있는 자 외선-가시광선 분광광도계를 이용한 비색법(21)으로 정량 분석하였으나 정확성과 재현성 등에 한계가 있다. 푸코이 단과 이를 구성하는 단당류는 화학구조상 전자전이와 발색 단이 존재하지 않아 자외선을 흡수에 의한 저농도 분석이 불가능하여 $\mathrm{HPLC}$ 의 시차 굴절율 검출기(differential refractive index detector, RID)나 휘발성 화합물로 유도체화 

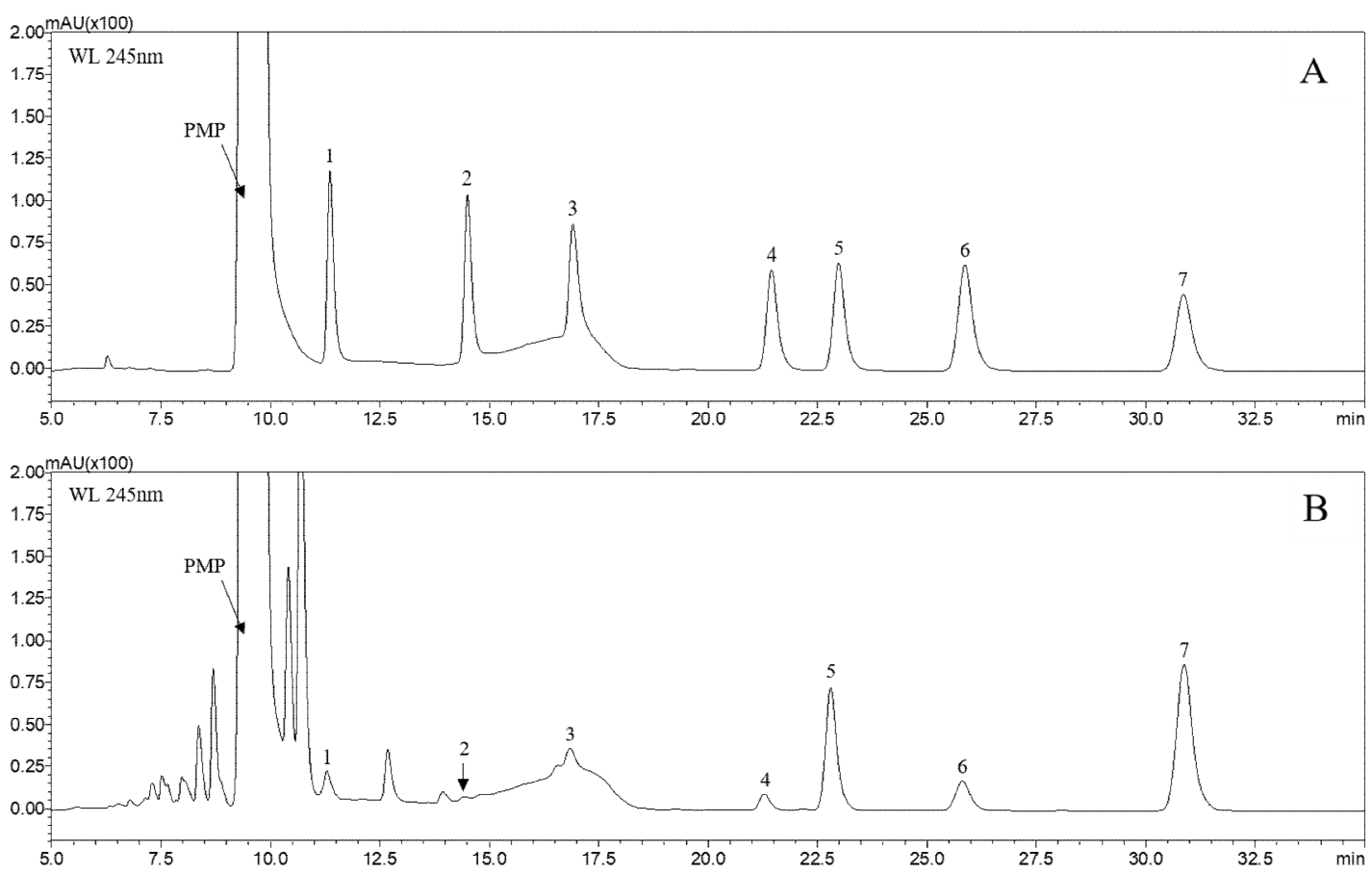

Fig. 1. UPLC chromatogram of PMP-labeled monosaccharide standards (A) and PMP-derivatives of acid hydrolysates of $\boldsymbol{S}$. horneri (B). Peak 1, mannose (Man); 2, rhamnose (Rha); 3, glucuronic acid (GlcA); 4, glucose (Glc); 5, galactose (Gal); 6, xylose (Xyl); 7, fucose (Fuc).

한 기체 크로마토그래피법에 의해 분석(22)하였으나 낮은 감도와 유도체화물의 안정성이 떨어지는 문제가 있다. 이 에 Honda 등(13)에 의해 고안된 PMP 유도체화법을 토대로 UPLC-DAD(-ESI)-TOF/MS 분석법을 적용하여 해조류 유 래 푸코이단의 단당류 조성을 확인하기 위한 PMP-sugars 분리 특성을 검토하였다.

PMP 유도체화 방법은 desialylation 또는 desulfation이 일어나지 않는 비교적 낮은 온도 조건에서 단당류와 결합된 bis-PMP 유도체화물(PMP-sugars)이 염기성 수용액에서 약 한 음이온의 성질을 띠고, $245 \mathrm{~nm}\left(\varepsilon=30,000 \mathrm{~L} \cdot \mathrm{mol}^{-1} \cdot \mathrm{cm}^{-1}\right)$ 에 서 최대 흡광이 일어나 전기화학적 검출이 가능한 것으로 보고되었다(23). 이에 본 연구에서는 가수분해된 괭생이모 자반 원물과 혼합표준용액을 PMP 유도체화 반응 후 $\mathrm{UPLC}-\mathrm{DAD}$ 에 의해 분석하였으며, PMP-sugars로 각각 분 리된 peak에 대해 200-600 nm 범위에서 UV 스펙트럼을 확인한 결과, $\lambda_{\max }$ 는 $245 \mathrm{~nm}$ 로 나타나 Suzuki와 Honda(23) 의 결과와 일치하는 것으로 확인되었다. PMP-sugars에 대 하여 UPLC를 이용한 분리조건을 Rao 등(24)의 방법을 적용 하였으나 PMP-galactose(PMP-Gal), -xylose(-Xyl) 및 -fucose (-Fuc)가 분리되지 않았고 PMP-sugars의 꼬리끌림 현상 (peak tailing)이 일어나 이동상의 조성과 용리 조건(elution mode)을 재설정하였다. 이동상으로 $100 \mathrm{mM}$ ammonium acetate(A)와 acetonitrile(B) 혼합용매의 비율을 달리하며 PMP-sugars의 머무름 시간(retention time, $t_{R}$ )을 비교하였다. 그 결과, 초기 $10 \%(\mathrm{v} / \mathrm{v})$ acetonitrile로 $5 \mathrm{~min}$ 동안 유지한
후 20\%(v/v) acetonitrile로 상승시켜 일정 시간 동안 유지하 였을 때 잔류 PMP 피크의 간섭 영향을 받지 않고 PMP-sugars의 분리능(resolution)이 1.5 이상으로 나타났다 (Fig. 1). 또한 PMP-sugars의 분리에 대한 이동상의 $\mathrm{pH}$ 의 영향 을 관찰하였는데 $\mathrm{pH}$ 증가에 따라 $\mathrm{t}_{\mathrm{R}}$ 은 감소하는 경향으로 나타났고, $\mathrm{pH} 7$ 이상에서 PMP-rhamnose와 PMP-glucuronic acid의 용출 순서가 역전되는 것으로 확인되었다(Fig. 2).

UPLC에 의해 분리된 개별 PMP-sugars 성분은 ESI-TOF/ $\mathrm{MS}$ 를 이용하여 positive ion mode에서 분석하였고 질량 스 펙트럼(mass spectrum)의 molecular ion peak의 이온 패턴 특성을 고려하여 동정하였다(Table 1). PMP-sugars는 $[\mathrm{M}+\mathrm{H}]^{+}$과 $[\mathrm{M}+\mathrm{K}]^{+}$의 이온 형식으로 나타났으며 fucose 등 의 aldose와 ketose 형식의 다당류 모두 carbodiimide $(\mathrm{RN}=\mathrm{C}=\mathrm{NR})$ 와 축합반응에 의해 결합된 bis-PMP 유도체화 물(Fig. 3)(13)로 확인되어 PMP 유도체화 반응이 해리 (dissociation)되지 않고 안정적으로 분석되는 것을 확인하 였다. Peak 1, 4 및 5는 $\mathrm{m} / \mathrm{z}$ 510.2187, [M+H] 과 $\mathrm{m} / \mathrm{z}$ $549.1746,[\mathrm{M}+\mathrm{K}]^{+}$의 모분자 이온(molecular ion)이 동일하 게 확인되었으며 구조적 차이에 따라 aldohexose인 mannose, glucose 및 galactose peak의 용출시간이 차이가 나는 것으로 나타났다. Peak 2, 7은 m/z 495.2238, $[\mathrm{M}+\mathrm{H}]^{+}$의 molecular ion이 검출되어 methyl pentose로 rhamnose(6deoxy-L-mannose)와 fucose(6-deoxy-L-galactose)로 확인하 였다. Peak 3은 m/z 525.1980, $[\mathrm{M}+\mathrm{H}]^{+}$이 검출되어 glucuronic acid로 동정되었다. 특히 glucuronic acid는 glucose에서 유 

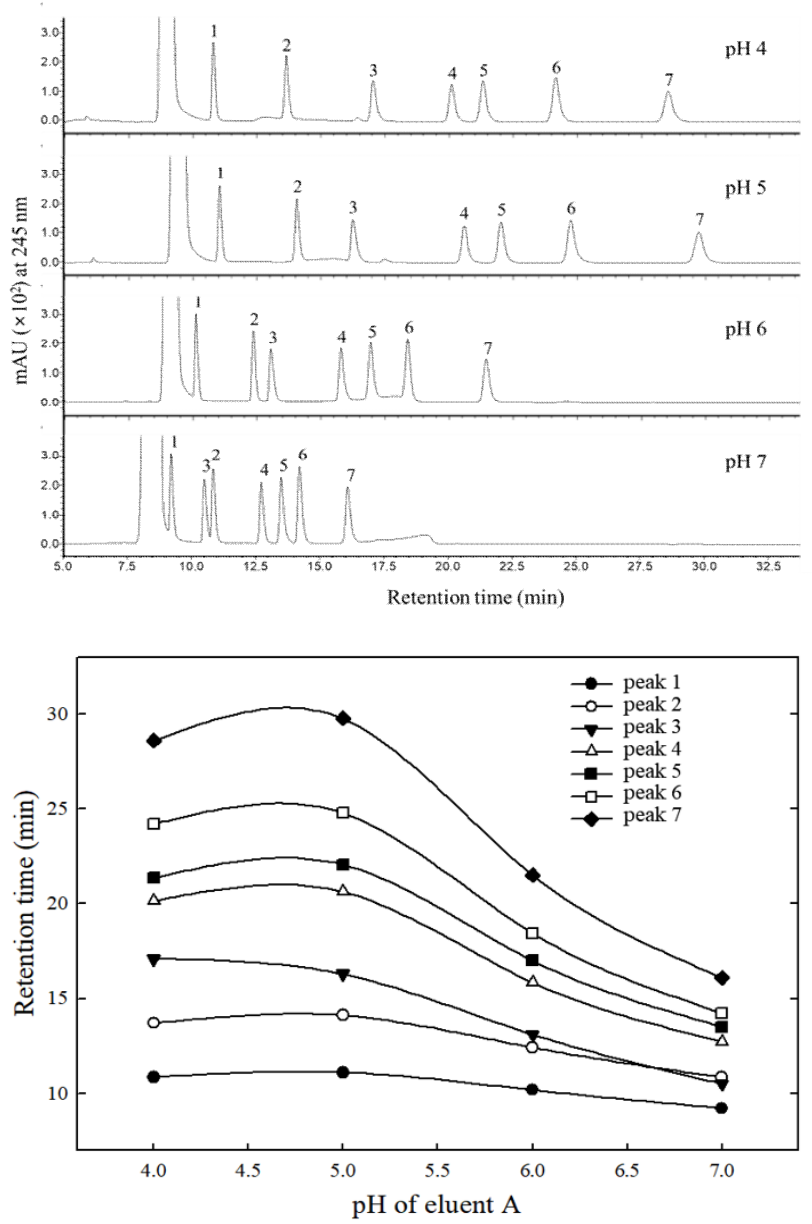

Fig. 2. Effect of $\mathrm{pH}$ values of the chromatographic eluent on retention times.

Peak 1, mannose (Man); 2, rhamnose (Rha); 3, glucuronic acid (GlcA); 4, glucose (Glc); 5, galactose (Gal); 6, xylose (Xyl); 7, fucose (Fuc).

Eluent, $20 \%(\mathrm{v} / \mathrm{v})$ acetonitrile in $100 \mathrm{mM}$ ammonium acetate buffer. Analytical condition was described in Table 1.
도되는 당산(sugar acid)의 일종인 hexuronic acid으로서 해 조류 등의 구조다당류의 구성성분으로 존재하는 것으로 알려져 있다. 또한 peak 6은 m/z 481.2028, [M+H] ${ }^{+}$와 m/z $519.1640,[\mathrm{M}+\mathrm{K}]^{+}$의 molecular ion이 검출되어 aldopentose 일종인 xylose으로 동정하였다(Fig. 4).

\section{분석법 유효성 검증}

괭생이모자반 푸코이단의 구성 단당류의 조성 및 함량 확인을 위한 UPLC-DAD 분석법 유효성 검증 결과는 Table 2과 같이 나타났다. Mannose 등 6종의 당류의 혼합표준용 액을 $10-500 \mathrm{mg} / \mathrm{L}$ 의 범위로 단계적으로 희석한 후 유도체 화 후 UPLC로 분석하여 각 당류의 검량선을 작성하고 상관 계수 $\left(\mathrm{r}^{2}\right)$ 를 산출하여 직선성을 확인하였다. PMP-sugars으 로서 mannose, rhamnose, glucuronic acid, glucose, galactose, xylose 및 fucose의 $r^{2}$ 은 0.9999 이상으로 모두 우수한 직선 성을 나타내었다. 정밀성은 괭생이모자반 열수추출물 시료 를 대상으로 1 일 5 회 반복 분석하였고 그 결과, 각 피크 면적의 상대표준편차(\% RSD)는 0.03-0.63\%으로 나타나 $\mathrm{AOAC}$ 가이드라인(25) 기준인 $1 \%$ 이하에 충족하였다. 정확 성은 회수율을 측정하여 나타내었다. 괭생이모자반 추출물 시료에 $20,50100 \mathrm{mg} / \mathrm{L}$ 의 혼합표준용액을 첨가하여 UPLC 로 분석하고 검량선에 근거하여 회수되는 시료 양을 백분율 로 계산하여 회수율을 산출하였다. 각 당류의 첨가된 표준 농도에 따라 mannose의 회수율은 98.45-108.21\%으로 나타 났고 rhamnose 97.32-101.31\%, glucuronic acid 89.21-97,87\%, glucose 92.76-103.56\%, galactose 98.56-106.21\%, xylose 94.53-109.76\% 그리고 fucose 97.11-105.21\%로 확인되어 $\mathrm{AOAC}$ 가이드라인(25)인 70-125\% 미만에 모두 충족하였 다. 검출한계와 정량한계는 의약품 등 시험법 밸리데이션 가이드라인(26)의 반응의 표준편차와 검량선의 기울기에

Table 1. Identified seven monosaccharides of chromatographical and their mass spectrometric data from the fucoidan of $S$. horeneri

\begin{tabular}{|c|c|c|c|c|c|c|c|c|c|}
\hline \multirow{2}{*}{$\begin{array}{c}\text { Peak } \\
\#\end{array}$} & \multirow{2}{*}{$\underset{(\mathrm{min})}{\mathrm{t}_{\mathrm{R}}}$} & \multirow{2}{*}{$\begin{array}{l}\lambda_{\max } \\
(\mathrm{nm})\end{array}$} & \multicolumn{5}{|c|}{ ESI(+)-TOF/MS result } & \multicolumn{2}{|c|}{ Identification } \\
\hline & & & Ion & $\begin{array}{l}\text { Meas. mass } \\
(\mathrm{m} / \mathrm{z})\end{array}$ & $\begin{array}{c}\text { Theor. mass } \\
(\mathrm{m} / \mathrm{z})\end{array}$ & $\begin{array}{l}\text { Error } \\
(\mathrm{mDa})\end{array}$ & $\begin{array}{l}\text { Predicted formula } \\
\text { (bis PMP-sugars) }\end{array}$ & Compound & M.F. \\
\hline 1 & 11.10 & 247 & $\begin{array}{l}{[\mathrm{M}+\mathrm{H}]^{+}} \\
{[\mathrm{M}+\mathrm{K}]^{+}}\end{array}$ & $\begin{array}{l}511.2152 \\
549.1693\end{array}$ & $\begin{array}{l}511.2187 \\
549.1746\end{array}$ & $\begin{array}{l}-3.5 \\
-5.3\end{array}$ & $\mathrm{C}_{26} \mathrm{H}_{30} \mathrm{~N}_{4} \mathrm{O}_{7}$ & Mannose & $\mathrm{C}_{6} \mathrm{H}_{12} \mathrm{O}_{6}$ \\
\hline 2 & 14.11 & 246 & {$[\mathrm{M}+\mathrm{H}]^{+}$} & 495.2192 & 495.2238 & -4.6 & $\mathrm{C}_{26} \mathrm{H}_{30} \mathrm{~N}_{4} \mathrm{O}_{6}$ & Rhmnose & $\mathrm{C}_{6} \mathrm{H}_{12} \mathrm{O}_{5}$ \\
\hline 3 & 16.29 & 246 & {$[\mathrm{M}+\mathrm{H}]^{+}$} & 525.1935 & 525.1980 & -4.5 & $\mathrm{C}_{26} \mathrm{H}_{28} \mathrm{~N}_{4} \mathrm{O}_{8}$ & Glucuronic acid & $\mathrm{C}_{6} \mathrm{H}_{10} \mathrm{O}_{7}$ \\
\hline 4 & 20.64 & 247 & $\begin{array}{l}{[\mathrm{M}+\mathrm{H}]^{+}} \\
{[\mathrm{M}+\mathrm{K}]^{+}}\end{array}$ & $\begin{array}{l}511.2125 \\
549.1693\end{array}$ & $\begin{array}{l}511.2187 \\
549.1746\end{array}$ & $\begin{array}{l}-6.2 \\
-5.3\end{array}$ & $\mathrm{C}_{26} \mathrm{H}_{30} \mathrm{~N}_{4} \mathrm{O}_{7}$ & Glucose & $\mathrm{C}_{6} \mathrm{H}_{12} \mathrm{O}_{6}$ \\
\hline 5 & 22.07 & 247 & $\begin{array}{l}{[\mathrm{M}+\mathrm{H}]^{+}} \\
{[\mathrm{M}+\mathrm{K}]^{+}}\end{array}$ & $\begin{array}{l}511.2169 \\
549.1683\end{array}$ & $\begin{array}{l}211.2187 \\
549.1746\end{array}$ & $\begin{array}{l}-1.8 \\
-6.3\end{array}$ & $\mathrm{C}_{26} \mathrm{H}_{30} \mathrm{~N}_{4} \mathrm{O}_{7}$ & Galactose & $\mathrm{C}_{6} \mathrm{H}_{12} \mathrm{O}_{6}$ \\
\hline 6 & 24.79 & 247 & $\begin{array}{l}{[\mathrm{M}+\mathrm{H}]^{+}} \\
{[\mathrm{M}+\mathrm{K}]^{+}}\end{array}$ & $\begin{array}{l}481.2035 \\
519.1587\end{array}$ & $\begin{array}{l}481.2082 \\
519.1640\end{array}$ & $\begin{array}{l}-4.7 \\
-5.3\end{array}$ & $\mathrm{C}_{25} \mathrm{H}_{28} \mathrm{~N}_{4} \mathrm{O}_{6}$ & Xylose & $\mathrm{C}_{5} \mathrm{H}_{10} \mathrm{O}_{5}$ \\
\hline 7 & 29.78 & 247 & {$[\mathrm{M}+\mathrm{H}]^{+}$} & 495.2199 & 495.2238 & -3.9 & $\mathrm{C}_{26} \mathrm{H}_{30} \mathrm{~N}_{4} \mathrm{O}_{6}$ & Fucose & $\mathrm{C}_{6} \mathrm{H}_{12} \mathrm{O}_{5}$ \\
\hline
\end{tabular}


Table 2. Result of method validation for the derivatized monosaccharides

\begin{tabular}{cccccccc}
\hline $\begin{array}{c}\text { Peak } \\
\#\end{array}$ & Monosaccharide & $\begin{array}{c}\text { Calibration } \\
\text { curve }\end{array}$ & $\begin{array}{c}\text { Correlation } \\
\text { coefficient } \\
\left(\mathrm{r}^{2}\right)\end{array}$ & $\begin{array}{c}\text { Precision }{ }^{1)} \\
(\% \text { RSD })\end{array}$ & $\begin{array}{c}\text { Accuracy } \\
(\%)\end{array}$ & $\begin{array}{c}\text { LOD } \\
(\mathrm{ug} / \mathrm{mL})\end{array}$ & $\begin{array}{c}\text { LOQ } \\
(\mathrm{ug} / \mathrm{mL})\end{array}$ \\
\hline 1 & Mannose & $\mathrm{y}=24011 \mathrm{x}-1143$ & 0.99996 & 0.52 & $98.45-108.21$ & 2.13 & 6.46 \\
2 & Rhamnose & $\mathrm{y}=23929 \mathrm{x}-27180$ & 0.99996 & 0.42 & $97.32-101.31$ & 1.60 & 4.85 \\
3 & Glucuronic acid & $\mathrm{y}=21409 \mathrm{x}+99533$ & 0.99991 & 0.36 & $89.21-97.87$ & 1.03 & 3.13 \\
4 & Glucose & $\mathrm{y}=21549 \mathrm{x}+10714$ & 0.99994 & 0.18 & $92.76-103.56$ & 1.03 & 3.11 \\
5 & Galactose & $\mathrm{y}=24412 \mathrm{x}-11303$ & 0.99999 & 0.69 & $98.56-106.21$ & 1.14 & 3.46 \\
6 & Xylose & $\mathrm{y}=30281 \mathrm{x}-35587$ & 0.99999 & 0.29 & $94.53-109.76$ & 1.14 & 3.44 \\
7 & Fucose & $\mathrm{y}=23932 \mathrm{x}-12315$ & 0.99995 & 0.30 & $97.11-105.21$ & 0.76 & 2.31 \\
\hline
\end{tabular}

1)Precision was evaluated using five replicates performed on a intra-day.

${ }^{2)}$ Accuracy was measured of the closeness of the analytical result of the true value determined by analyzing a spiked sample.

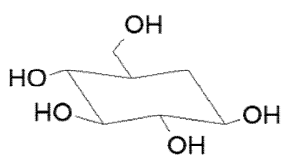

Monosaccharide<smiles>CC1=NN(c2ccccc2)C(=O)C1</smiles>

PMP



Bis-PMP derivative

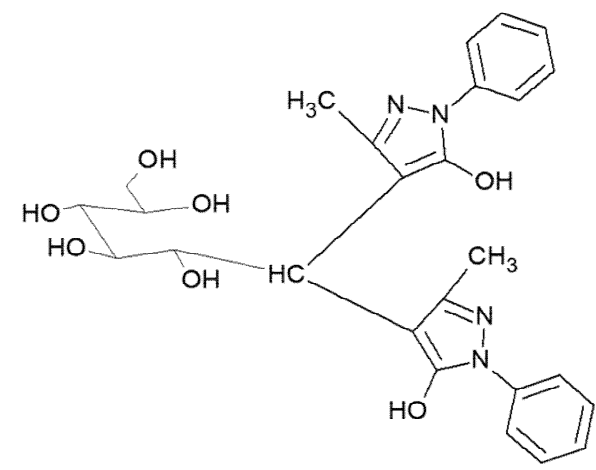

(PMP) reagent.
근거하는 방법으로 계산하였다. 각 당류 검출한계는 0.76-2.13 mg/L였으며, 정량한계는 2.31-6.46 mg/L로 나타 났다. 이와 같은 분석법의 유효성 검증을 통해 전처리 방법 을 포함한 상기 UPLC 분석법을 이용한 해조류 유래 푸코이 단의 당류 조성 확인 분석 결과의 신뢰성을 확보할 수 있었 다. 일반적으로 유도체화 방법을 선택할 때 column 분리 전후 목적성분에 대한 추가적인 전처리, 최적의 반응시간, 고가의 시약 소모, 반응온도 및 반응 부산물 생성 등 분석에 영향을 미칠 수 있는 요소들을 고려하여야 한다. 또한 각 분석물질에 대한 유도체 화합물 형성여부와 함께 높은 수 율, 재현성 및 안전성에 고려도 중요한 요소 중 하나이다 (27). Honda 등(13)이 고안한 PMP 유도체화 반응을 적용한 UPLC-DAD-TOF/MS 분석법은 유도체화 시약의 분해와 반 응 부산물 생성 등, 분석에 영향을 미칠 수 있는 요소가 거의 없어 안정적으로 해조류의 푸코이단의 당류 조성과 그 함량을 확인할 수 있었다.

\section{괭생이모자반 푸코이단의 단당류 함량}

괭생이모자반(S. horneri)은 한국, 일본 및 중국 연안에 폭넓게 분포하고 있으며, 바다숲 조성과 해양환경 복원에
있어 중요한 수산자원이며, 푸코이단 등 기능성 다당류가 풍부하여 식품 산업적으로 활용가치가 있다. 일본의 경우, 종묘생산 및 양식 기술개발이 활발하며 각종 조리과정의 식용재료로 사용되고 있다. 국내의 경우 2016년 5월 식약처 에 괭생이모자반을 식품 원료로 등재하였고 최근 괭생이모 자반을 활용한 기능성 식품 소재 개발에 관한 연구가 활발 하다. 더불어 괭생이모자반의 기능성 규명과 함께 기능성 다당류인 푸코이단의 구조 결정과 분석법에 대한 연구도 대두되고 있으나 현재까지 해조류의 푸코이단의 추출 및 분석방법에 대한 공인분석법이 명확하지 않은 실정이다. 이에 괭생이모자반 유래 푸코이단의 구조 결정에 앞서 본 연구에서 분석법 유효성 검증에 의해 분석결과의 신뢰성을 확보하였고 PMP-유도체화와 UPLC 분석법을 이용하여 괭 생이모자반 유래 푸코이단의 당류 조성과 각 함랑을 분석하 였다. 시료는 괭생이모자반 건조원물과 정제수를 이용하여 $90^{\circ} \mathrm{C}$ 에서 4 시간 동안 열수추출 후 감압농축과 동결건조한 괭생이모자반 추출물을 조제하여 푸코이단의 구성 당류조 성을 확인하였다. 본 실험에 앞서 가수분해하지 않는 괭생 이모자반 건조원물과 추출물을 공시료로써 유도체화 후 UPLC로 분석한 결과 당류가 검출되지 않아 유리당 형태의 

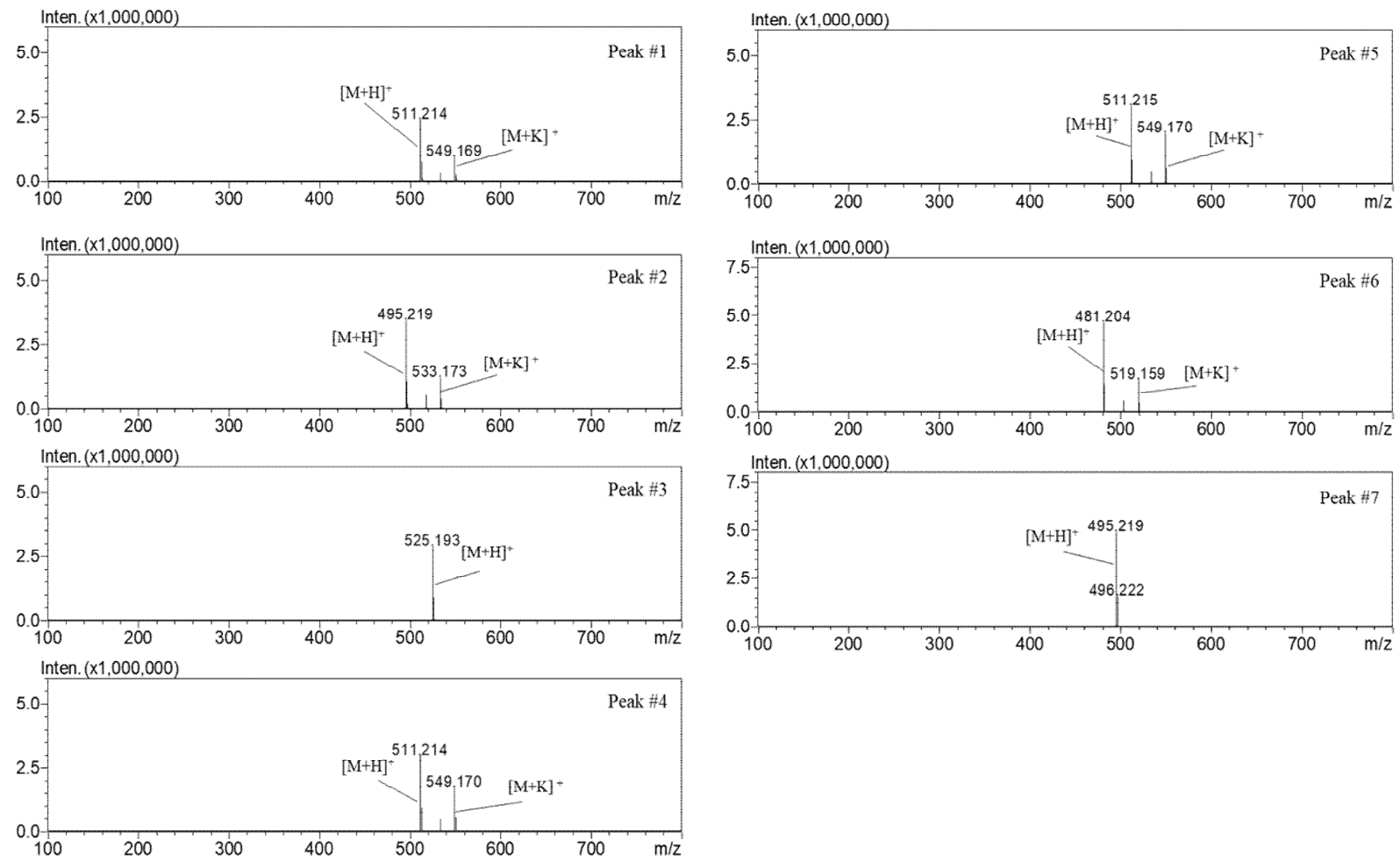

Fig. 4. Mass spectra of PMP-sugars derivatization in Electrospray ionization (positive ion mode) TOF/MS analysis.

Peak 1, mannose (Man); 2, rhamnose (Rha); 3, glucuronic acid (GlcA); 4, glucose (Glc); 5, galactose (Gal); 6, xylose (Xyl); 7, fucose (Fuc).

당류는 시료내 존재하지 않는 것을 확인하였다(data not shown). 괭생이모자반 건조원물과 추출물을 가수분해 및 유도체화 후 UPLC로 분석한 결과는 Table 3 와 같이 나타났 다. 괭생이모자반 유래 푸코이단의 함량은 구성 단당류를 합한 총량은 건조원물 $54.63 \mathrm{mg} / \mathrm{g}$, 열수추출물 $172.31 \mathrm{mg} / \mathrm{g}$ 으로 확인되었다. Fucose와 galactose 순으로 건조원물과 열수추출물 모두에서 가장 많은 함량을 보였으며, 이는 Percival 등(7)의 갈조류의 푸코이단이 fucose와 galactose가 주성분으로 결합된 구조인 것으로 보고된 내용과 일치한 결과를 보였다, 이외 fucose, galactose를 제외한 xylose외 단당류의 구성은 괭생이모자반 원물과 열수추출물 간의 푸코이단을 구성하는 단당류의 함량이 상이한 것으로 나타 나 향후 이와 관련된 추가 연구가 필요할 것으로 사료된다. 모자반 종류에 따라 푸코이단의 구성 단당류인 fucose의 함량이 Ale 등(28)에는 26-76\%, Duarte 등(29)에서는 35-67.8\%으로 보고되었고 이외 단당류의 함량에 대한 연구 가 미비한 실정이다. 본 연구에서 수행한 괭생이모자반 건 조시료, 열수추출물에서는 fucose의 함량은 $51.55 \%, 59.09 \%$ 으로 나타났다.

향후 명확한 괭생이모자반 푸코이단의 구조 해석에 관한 연구가 필요 할 것으로 사료되며, 본 연구에 확립된 분석법 이 해조류 활용한 기능성 식품 개발에 기여할 수 있을 것으 로 기대된다.
Table 3. Content of monosaccharide of fucoidan from $S$. horneri

\begin{tabular}{cccc}
\hline \multirow{2}{*}{ Monosaccharide $^{1)}$} & \multicolumn{2}{c}{ Content (mg/g dried weight) } & \multirow{2}{*}{ t-value } \\
\cline { 2 - 3 } & Raw material & Hot-water extract & \\
\hline Man & $2.23 \pm 0.06^{2)(3)}$ & $5.62 \pm 0.12^{\mathrm{c}}$ & $-31.033^{* 4)}$ \\
Rha & $1.23 \pm 0.01^{\mathrm{b}}$ & $1.78 \pm 0.03^{\mathrm{a}}$ & $-7.306^{* *}$ \\
GlcA & $0.34 \pm 0.01^{\mathrm{a}}$ & $2.60 \pm 0.01^{\mathrm{b}}$ & $-39.952^{*}$ \\
Glc & $2.01 \pm 0.04^{\mathrm{c}}$ & $17.31 \pm 0.61^{\mathrm{e}}$ & $-142.467^{*}$ \\
Gal & $16.34 \pm 0.42^{\mathrm{e}}$ & $34.06 \pm 0.41^{\mathrm{f}}$ & $-167.939^{*}$ \\
Xyl & $4.32 \pm 0.08^{\mathrm{d}}$ & $9.12 \pm 0.32^{\mathrm{d}}$ & $-28.449^{* *}$ \\
Fuc & $28.16 \pm 0.42^{\mathrm{f}}$ & $101.82 \pm 2.85^{\mathrm{g}}$ & $-220.816^{*}$ \\
\hline
\end{tabular}

${ }^{1)}$ Man, mannose; Rha, rhamnose; Glc A, glucuroic acid; Glc, glucose; Gal, galactose; Xyl, xylose; Fuc, fucose.

${ }^{2)}$ Values are mean \pm SD

${ }^{3)}$ Values with different letters within the same column are significantly different $(\mathrm{p}<0.05)$ by Turkey $b$ range test.

${ }^{4)^{*}} \mathrm{p}<0.01,{ }^{* *} \mathrm{p}<0.001$; significant difference between raw material and hot-water extract is indicated by $\mathrm{t}$-test.

\section{요 약}

본 연구는 국내 남해안 일대와 제주지역으로 대량 유입 되고 있는 괭생이모자반(S. horneri) 유래 푸코이단의 단당 류 조성 분석을 위한 PMP 유도체화와 UPLC-DAD-TOF/ 
MS 분석법 적용을 검토하고 구성 단당류의 조성 및 함량을 확인하였다. 괭생이모자반의 푸코이단을 $2 \mathrm{M} \mathrm{TFA}$ 를 이용 하여 가수분해하고 이를 3-methyl-1-phenyl-5-pyrazolone (PMP)과 반응시켜 유도체화 하였다. 유도체화물인 PMPsugars를 분리하기 위한 분석 조건으로 octadecyldimethylsilyl (ODS) column을 사용하고, 이동상은 암모늄 아세테이트 완충액과 아세토니트릴 혼합용매로서 $\mathrm{pH} 5.0$ 을 최적조건 으로 설정하였다. PMP-sugars의 검출은 UV 스펙트럼과 질 량 스펙트럼의 확인을 통해 동정할 수 있었으며 특히, 질량 스펙트럼 확인 결과, $[\mathrm{M}+\mathrm{H}]^{+}$과 $[\mathrm{M}+\mathrm{K}]^{+}$의 이온 형식으로 carbodiimide $(\mathrm{RN}=\mathrm{C}=\mathrm{NR})$ 와 축합반응에 의해 결합된 bis-PMP 유도체화물로서 유도체화 반응이 해리되지 않고 안정적으 로 분석되는 것을 확인하였다. 본 분석방법을 검증하기 위 해 mannose 등 단당류 7종의 혼합표준용액을 이용하여 직 선성, 정밀성, 회수율을 각각 측정하였다. 검량선의 상관계 수는 0.9999 이상으로 우수한 직선성을 보였으며 $\mathrm{LOD}$ 와 $\mathrm{LOQ}$ 는 각각 0.76-2.13 mg/L과 2.31-6.46 mg/L으로 나타났 다. 회수율은 89.21-109.76\%이고 반복 정밀성으로 상대표 준편차(\% RSD)는 $0.03-0.63 \%$ 으로 나타나 $\mathrm{AOAC}$ 등의 기 준규격에 적합한 것을 확인하였다. 본 시험법에 따라 괭생 이모자반(S. horneri) 유래 푸코이단의 당류 조성과 함량을 분석하였으며 mannose, glucose, galactose, xylose, glucuronic acid, rhamnose, fucose으로 구성되어 있는 것을 확인하였다. Fucose의 함량이 푸코이단 구성 단당으로 $50 \%$ 이상 함유되어 있는 것으로 나타났고, 괭생이모자반 원물 과 열수추출물 간의 푸코이단을 구성하는 단당류의 함량이 상이한 것으로 확인되었다. 향후 괭생이모자반를 활용한 기능성 원료 개발을 위한 표준화와 규격화를 위한 기초자료 서 크게 활용될 것으로 기대된다.

\section{감사의 글}

본 연구는 산업통상자원부의 경제협력권산업 육성사업 (과제명: 초임계추출을 이용한 괭생이 모자반 생리활성소 재 개발 및 양식어류 사료첨가제 개발, 과제번호: P0000611) 연구지원에 의해 수행한 결과의 일부이며, 이에 본 과제 지원에 감사드립니다.

\section{References}

1. Jimenez-Escrig A, Goni Cambrodon I (1999) Nutritional evaluation and physiological effects of edible seaweeds. Arch Latinoam Nutr, 49, 114-120

2. Ruperez P, Ahrazem O, Leal JA (2002) Potential antioxidant capacity of sulfated polysaccharides from the edible marine brown seaweed Fucus vesiculosus. J Agric Food Chem, 50, 840-845

3. Kylin H (1913) Zur biochemie der meeresalgen. Hoppe-Seyler's Z Physiol Chem, 83, 171-197

4. Vasseur E (1948) Chemical studies on the jelly coat of the sea urchin egg. Acta Chem Scand, 2, 900-913

5. Nagaoka M, Shibata H, Kimura-Takagi I, Hashimoto S, Aiyama R, Ueyama S, Yokokura T (2000) Anti-ulcer effects and biological activities of polysaccharides from marine algae. BioFactors, 12, 267-274

6. Percival E, Ross AG (1950) The isolation and purification of fucoidan from brown seaweed. J Chem Soc, 0, 717-720

7. Percival E, Mcdowell RH (1967) Chemistry and enzymology of marine algal polysacchrides. Academic Press, New York, NY, USA p 219

8. Mian AJ, Percival E (1973) Carbohydrates of the brown seaweeds Himanthalia lorea, Bifucaria bifurcata and Padina pavonia: part $\Pi$. structural studies of the "fucan". Carbohydr Res, 26, 147-161

9. Kang JY, Khan MN, Park NH, Cho JY, Lee MC, Fujii H, Hong YK (2008) Antipyretic, analgesic, and anti-inflammatory activities of the seaweed Sargassum fulvellum and Sargassum thunbergii in mice. $\mathrm{J}$ of Ethnopharmacol, 116, 187-190

10. Yuan YV, Walsh NA (2006) Antioxidant and antiproliferative activities of extracts from a variety of edible seaweeds. Food Chemical Toxicol, 44, 1144-1150

11. Val A, Platas G, Basilio A, Cabello A, Gorrochategui J, Suay I, Vicente F, Portillo E, Rio M, Reina G, Pelaez F (2001) Screening of antimicrobial activities in red, green and brown macroalgae from Gran Canaria. Int Microbiol, 4, 35-40

12. Pushpamali WA, Nikapitiya C, De Zoysa M, Whang b I, Kim SJ b, Lee J (2008) Isolation and purification of an anticoagulant from fermented red seaweed Lomentaria catenata. Carbohydrate Polymers, 73, 274-279

13. Honda S, Akao E, Suzuki S, Okuda M, Kakehi K, Nakamura J (1989) High-performance liquid chromatography of reducing carbohydrates as strongly ultraviolet-absorbing and electrochemically sensitive 1-phenyl-3-methyl-5-pyrazolone derivatives. Anal Biochem, $180,351-357$

14. Fu DT, Oneill RA (1995) Monosaccharide composition analysis of oligosaccharides and glycoproteins by high-performance liquid chromatography. Anal Biochem, 227, 377-384

15. Honda S, Togashi K, Taga A (1997) Unusual separation 
of 1-phenyl-3-methyl-5-pyrazolone derivatives of aldoses by capillary zone electrophoresis. J Chromatogr A, 791, 307-311

16. Komatsu T, Tatsukawa K, Filippi JB, Sagawa T, Matsunaga D, Mikami A, Ishida K, Ajisaka T, Tanaka K, Aoki M, Wang WD, Liu HF, Zhang SD, Zhou MD, Sugimoto T (2007) Distribution of drifting seaweeds in eastern East China Sea. J Mar Syst, 67, 245-252

17. Yoshida T (1963) Studies on the distribution and drift of the floating seaweeds. Bull Tohoku Reg Fish Labratory, 23, 141-186

18. Hwang EK, Lee SJ, Ha DS, Park CS (2016) Sargassum golden tides in the Shinan-gun and Jeju island, Korea. Korean. J Fish Aquat Sci, 49, 689-693

19. Kim YM, KIM DS, Choi YS (2004) Anticoagulant activities of brown seaweed extracts in Korea. Korean J Food Sci Technol, 36, 1008-1013

20. Yoon JA, Yu KW, Jun WJ, Cho HY, Son YS, Yang HC (2000) Screening of antricoagulant activity on the extracts of edible seaweds and optimization of extraction condition. J Korean Soc Food Sci Nutr, 29, 1098-1106

21. Dische Z, Shettles LB (1948) A specific color reaction of methylpentoses and a spectrophotometric micromethod for their determination. J Biol Chem, 175, 595-603

22. Zhao ZQ, Liu XG, Niu XZ (2004) Determination of L-fucose in polysaccharide from Laminaria japonica by gas chromatography. Mar Sciences, 28, 10-12
23. Suzuki S, Honda S (1998) A tabulated review of capillary electrophoresis of carbonhydrates. Electrophoresis, 19, 2539-2560

24. Rao JH, Liu WY, Jiang JY (2007) Analysis of monosaccharide compositions in epimedium polysaccharide by precolumn derivation HPLC. Lishizhen Med Mater Med Res, 18, 366-367

25. AOAC (1996) Official Methods of Analysis. $15^{\text {th }}$ ed, Association of Official Analytical Chemists, Washington DC, USA, p 210-219

26. KFDA (2012) Analytical method guideline about validation of drugs and etc. Korea Food \& Drug Administration, Osong, Korea, p 1-26

27. Danielson ND, Gallagher PA, Bao JJ (2008) Chemical reagents and derivatization procedures in drug analysis. In : Encyclopedia of Anal Chem, Meyers RA(Editor), John Wiley \& Sons, Ltd. Hoboken, NY, USA. p 7042-7076

28. Ale MT, Mikkelsen JD, Meyer AS (2012) Designed optimization of a single-step extraction of fucosecontaining sulfated polysaccharides from Sargassum $s p$. J Appl Phycol, 24, 715-723

29. Duarate ME, Cardoso MA, Noseda MD, Cerezo AS (2001) Structural studies on fucoidans from the brown seaweed Sargassum stenophyllum. Carbohydr Res, 333, 281-293 